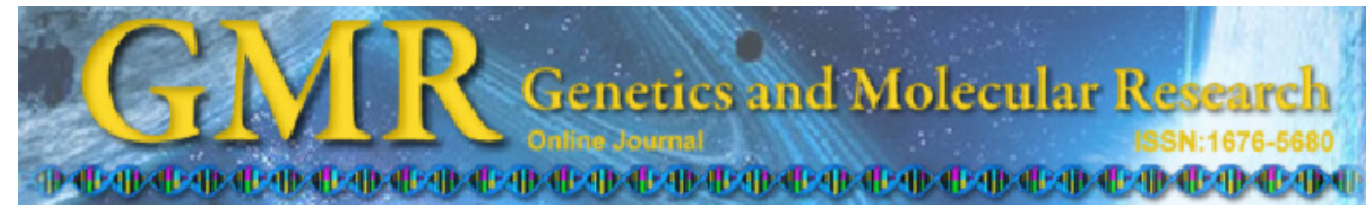

Research Note

\title{
New microsatellite markers for bananas (Musa spp)
}

\author{
E.P. Amorim ${ }^{1}$, P.H. Silva ${ }^{2}$, C.F. Ferreira ${ }^{1}$, V.B.O. Amorim ${ }^{1}$, V.J. Santos ${ }^{3}$, \\ A.D. Vilarinhos ${ }^{1}$, C.M.R. Santos ${ }^{4}$, M.T. Souza Júnior ${ }^{5}$ and R.N.G. Miller ${ }^{6}$ \\ ${ }^{1}$ Embrapa Mandioca e Fruticultura, Cruz das Almas, BA, Brasil \\ ${ }^{2}$ Universidade Federal de Lavras, Lavras, MG, Brasil \\ ${ }^{3}$ Universidade Federal do Recôncavo da Bahia, Cruz das Almas, BA, Brasil \\ ${ }^{4}$ Embrapa Recursos Genéticos e Biotecnologia, Brasília, DF, Brasil \\ ${ }^{5}$ Embrapa Agroenergia, Brasília, DF, Brasil \\ ${ }^{6}$ Departamento de Biologia Celular, Instituto de Ciências Biológicas, \\ Universidade de Brasília, Brasília, DF, Brasil \\ Corresponding author: E.P. Amorim \\ E-mail: edson@cnpmf.embrapa.br
}

Genet. Mol. Res. 11 (2): 1093-1098 (2012)

Received September 12, 2011

Accepted January 16, 2012

Published April 27, 2012

DOI http://dx.doi.org/10.4238/2012.April.27.8

\begin{abstract}
Thirty-four microsatellite markers (SSRs) were identified in EST and BAC clones from Musa acuminata burmannicoides var. Calcutta 4 and validated in 22 Musa genotypes from the Banana Germplasm Bank of Embrapa-CNPMF, which includes wild and improved diploids. The number of alleles per locus ranged from 2 to 14. The markers were considered highly informative based on their polymorphism information content values; more than $50 \%$ were above 0.5. These SSRs will be useful for banana breeding programs, for studies of genetic diversity, germplasm characterization and selection, development of saturated genetic linkage maps, and marker assisted selection.
\end{abstract}

Key words: Genetic breeding; Microsatellites; Primer validation; Musa spp 


\section{INTRODUCTION}

Bananas (Musa spp) are grown in more than 120 tropical and subtropical countries, mainly by small farmers. In 2010, the total harvested area and fruit production were approximately 4.7 million hectares and 102 million tons, respectively (FAO, 2012). Such numbers indicate the importance of bananas as a strong commodity, playing key economic and social roles in many countries producing bananas worldwide.

Banana breeding programs are currently focused on the introgression of diverse traits that range from disease resistance/tolerance to yield and fruit quality (Heslop-Harrison and Shawarzacher, 2007). Molecular genetic studies are of fundamental importance for increasing our knowledge base and resources for accelerated genetic improvement of the crop, by allowing the analysis of genetic diversity, construction of genetic linkage maps, and quantitative trait locus mapping of markers for alleles linked to resistance to biotic and abiotic stresses of particular importance. The availability of reliable and robust molecular markers such as simple sequence repeat (SSRs) might contribute to the acceleration of Musa breeding programs.

Although many Musa SSRs have been developed thus far by using a number of different strategies (Jarret et al., 1994; Crouch et al., 1997; Lagoda et al., 1998; Creste et al., 2003, 2006; Wang et al., 2008; Miller et al., 2010), the number of SSR loci available for genetic analysis is still limited, with many more validated and polymorphic SSRs required (Creste et al., 2004; Wang et al., 2009).

\section{MATERIAL AND METHODS}

A total of 52 SSR primer pairs were developed in this study from Musa acuminata expressed sequence tag and bacterial artificial chromosome clone consensus sequence data available in the DATA Musa database (http://bioinformatics.cenargen.embrapa.br/ musagene/tiki-index.php?page=DATAMUSA) (Togawa et al., 2010). For this, sequences were analyzed using an in-house bioinformatics pipeline that detects microsatellite loci on the basis of a PERL script that scans for imperfect repeat SSRs using the scan-formatches program (Dsouza et al., 1997). A maximum of 5 primer sets per SSR locus were designed using Primer3 (Rozen and Skaletsky, 2000). Optimization of polymerase chain reaction (PCR) amplification conditions was performed using the Fast PCR professional 5.2 software (http://www.biocenter.helsinki.fi/bi/programs/fastpcr.htm).

Microsatellites were then optimized and validated using $M$. acuminata accessions ranging from wild to improved diploids. For this, plantlets of 11 wild banana diploids (Burmanica, Calcutta-4, Microcarpa, Berlin, Lidi, Khai Nai On, Nyarma Yik, Jari Buaya, Raja Uter, Sowmuk, and Tjau Lagada) and 11 improved diploids (017041-01, SH32-63, 04207906, 013018-01, 003023-03, 013004-06, 001016-01, 091079-03, F2P2, 003115-Plant-1, and 15-Plant-2) from the Musa germplasm bank maintained at Embrapa Cassava and Fruits Research Centre (www.cnpmf.embrapa.br) were selected. These 22 diploids were chosen on the basis of agronomical characteristics and disease resistance.

Genomic DNA was extracted from young leaves of the wild and improved banana diploids by using the cetyltrimethylammonium bromide (CTAB) method proposed by Doyle 
and Doyle (1990). PCRs contained $30 \mathrm{ng}$ DNA, $1.5 \mathrm{mM} \mathrm{MgCl}, 100 \mu \mathrm{M}$ each dNTPs, $0.2 \mu \mathrm{M}$ each primer, and $0.75 \mathrm{U}$ Taq polymerase in $10 \mathrm{X}$ buffer (Biosystems) in a final reaction volume of $15 \mu \mathrm{L}$. Amplifications were carried out using a BIORAD MyCyclerThermal Cycler with the following amplification program: $94^{\circ} \mathrm{C}$ for $3 \mathrm{~min}$, followed by 30 cycles of $94^{\circ} \mathrm{C}$ for $40 \mathrm{~s}, 55^{\circ} \mathrm{C}$ for $40 \mathrm{~s}$ (annealing temperature modified according to the primer used), and $72^{\circ} \mathrm{C}$ for $1 \mathrm{~min}$. A final polymerase extension step at $72^{\circ} \mathrm{C}$ for 4 min was also included, followed by a final incubation at $10^{\circ} \mathrm{C}$. PCR optimization included identification of the optimal $\mathrm{MgCl}_{2}$ concentrations and annealing temperatures by using 3 different protocols. Amplification products were electrophoresed on $6 \%$ denaturing polyacrylamide gels and silver stained according to the protocol described by Creste et al. (2001). Allele size was estimated using a 50-bp ladder molecular size standard (Invitrogen).

\section{RESULTS AND DISCUSSION}

SSR markers combine several features of an ideal genetic marker, owing to their abundance and widespread dispersal in genomes, hypervariability, co-dominant nature, accessibility, reliability, and ease of interpretation (Gaudeul et al., 2004). Therefore, assessment of Musa genetic variability solely by using SSR markers continues to be widely used (e.g., Amorim et al., 2008; Jesus et al., 2009).

Of the 52 primer pairs tested in this study, 1 was monomorphic (data not shown), 3 did not yield any PCR product, and 14 required adjustment in PCR conditions. Thirty-four SSR primer combinations produced polymorphic DNA amplification products and were validated as being useful markers for genetic studies in Musa spp (Table 1).

The number of alleles per primer varied from 2 to 14 , with an average number of 5.73. Markers CNPMF-1, $-9,-15,-21,-24,-25$, and -56 presented the lowest number of alleles (2) and marker CNMPF-45 yielded the highest number of alleles (14). This CNPMF-series of SSR markers was classified according to their repeat motifs. The microsatellites were compared with the NCBI public database (http://www.ncbi.nih.gov/ BLAST/) using the BLASTx-Swissprot option. A cut-off E-value of $<10^{-5}$ was used to define similar orthologs and sequences that did not meet this requirement, which were annotated as unknown. The Hardy-Weinberg equilibrium (HWE) and linkage disequilibrium were accessed by the exact test, and the polymorphism information content (PIC) was calculated using the POWERMARKER software package (Liu and Muse, 2005). The expected heterozygosity $\left(H_{\mathrm{E}}\right)$ and observed heterozygosity $\left(H_{\mathrm{O}}\right)$ were determined using the GENETIX software (Version 4.03) (Belkhir et al., 1999). $H_{\mathrm{E}}$ varied among loci from 0.0868 to 0.8988 , with an average of 0.6526 , and $H_{\mathrm{O}}$ ranged from 0.0909 to 0.9474 . Thirty-eight percent of the loci showed a significant deviation from the HWE. The mean PIC values ranged from 0.083 to 0.8946 , with $\sim 70 \%$ showing a PIC value above 0.5000 .

These highly informative SSR markers might contribute to the acceleration of banana breeding programs worldwide, improving studies of genetic diversity and leading to the development of saturated genetic linkage maps. This would ultimately enable markerassisted selection and improve selection efficiency. 


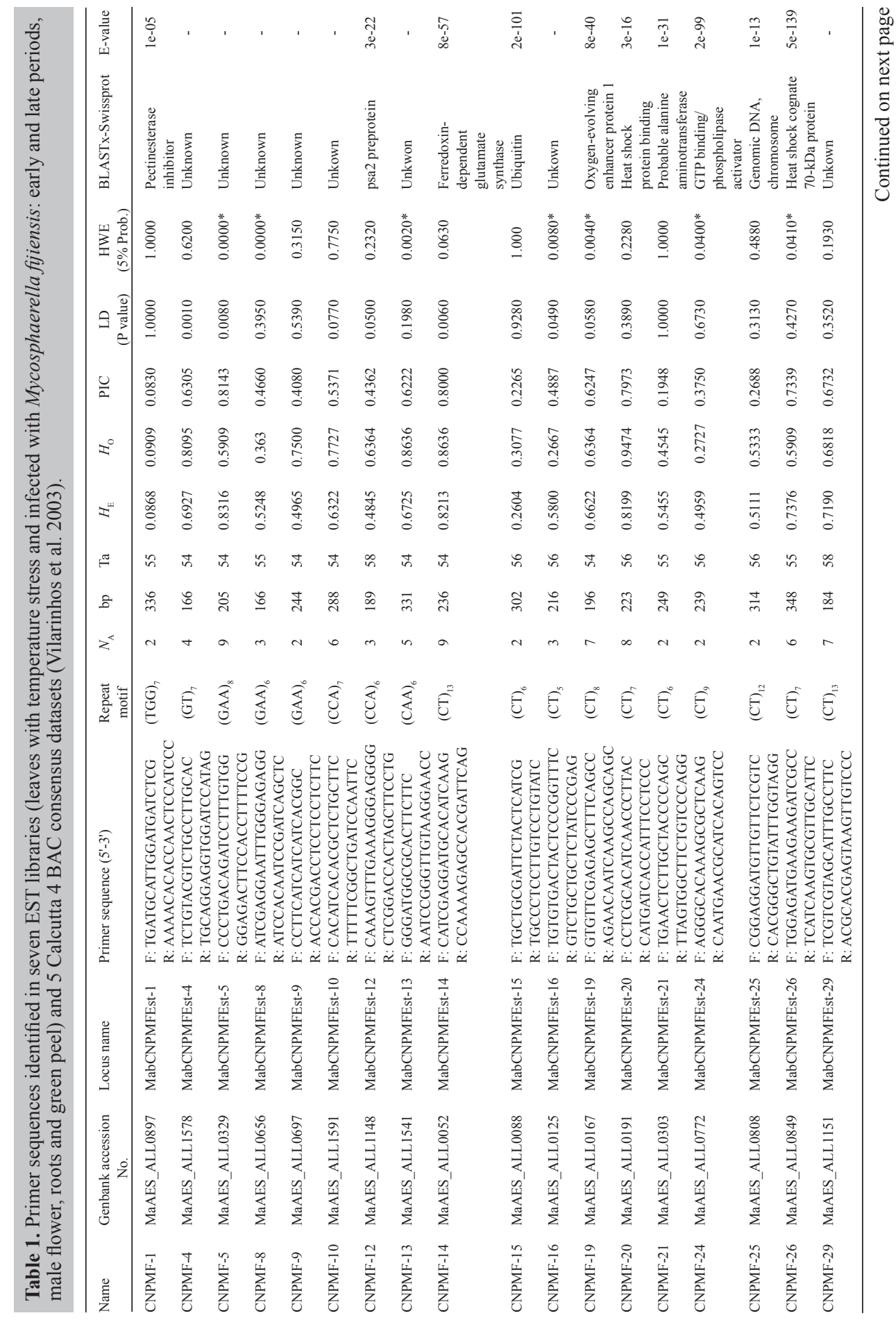









\section{ACKNOWLEDGMENTS}

Research partially supported by the CNPq - the National Council for Scientific and Technological Development (Project \#506165/2004-3) and Embrapa (Macroprograma 2 - Banana Genetic Breeding).

\section{REFERENCES}

Amorim EP, Reis RV, Santos-Serejao JA, Amorim VBO, et al. (2008). Variabilidade genética estimada entre diplóides de banana por meio de marcadores microssatélites. Pesq. Agropec. Bras. 43: 1045-1052.

Belkhir K, Boesa P, Goudet J, Chikhi L, et al. (1999). Genetix Lociciel Sous Windows TM pour la Genetique dés Populations Laboratoire Genome. CNRS UPR, Université de Montpellier II, Montpellier.

Creste S, Tulmann-Neto A and Figueira A (2001). Detection of single sequence repeat polymorphism in denaturing polyacrylamide sequencing gels by silver staining. Plant Mol. Biol. Rep. 19: 299-306.

Creste S, Tulmann-Neto A, Silva SO and Figueira A (2003). Genetic characterization of banana cultivars (Musa spp.) from Brazil using microsatellite markers. Euphytica 132: 259-268.

Creste S, Tulmann-Neto A, Vencovsky R, Silva SO, et al. (2004). Genetic diversity of Musa diploid and triploid accessions from the Brazililan banana breeding program estimated by microsatellite markers. Genet. Resour. Crop Evol. 51: 723-733.

Creste S, Benatti TR, Orsi MR and Risterucci A-M (2006). Isolation and characterization of microsatellite loci from a commercial cultivar of Musa acuminata. Mol. Ecol. Notes 6: 303-306.

Crouch JH, Crouch HK, Ortiz R and Jarret RL (1997). Microsatellite markers for molecular breeding of Musa. InfoMusa 6: 5-6.

Doyle JJ and Doyle JL (1990). Isolation of plant DNA from fresh tissue. Focus 12: 13-15.

Dsouza M, Larsen N and Overbeek R (1997). Searching for patterns in genomic data. Trends Genet. 13: 497-498.

FAO (2012). FAOSTAT. Available at [http://faostat.fao.org]. Accessed April 12, 2012.

Gaudeul M, Till-Bottraud I, Barjon F and Manel S (2004). Genetic diversity and differentiation in Eryngium alpinum L. (Apiaceae): comparison of AFLP and microsatellite markers. Heredity 92: 508-518.

Heslop-Harrison JS and Shawarzacher T (2007). Domestication, genomics and the future for banana. Ann. Bot. 100: 1073-1084.

Jarret RL, Bhat KV, Cregan P, Ortiz P, et al. (1994). Isolation of microsatellite DNA markers in Musa. InfoMusa 3: 3-4.

Jesus ON, Ferreira CF, Silva SO, Câmara TR, et al. (2009). Characterization of recommended banana cultivars using morphological and molecular descriptors. Crop Breed. Appl. Biotechnol. 9: 164-173.

Lagoda PJ, Noyer JL, Dambier D, Baurens FC, et al. (1998). Sequence tagged microsatellite site (STMS) markers in the Musaceae. Mol. Ecol. 7: 659-663.

Liu K and Muse SV (2005). PowerMarker: an integrated analysis environment for genetic marker analysis. Bioinformatics 21: 2128-2129.

Miller RN, Passos MA, Menezes NN, Souza MT Jr, et al. (2010). Characterization of novel microsatellite markers in Musa acuminata subsp. burmannicoides, var. Calcutta 4. BMC Res. Notes 3: 148.

Rozen S and Skaletsky H (2000). Primer3 on the www for general users and for biologist programmers. Methods Mol. Biol. 132: 365-386.

Vilarinhos AD, Piffanelli P, Lagoda P, Thibivilliers S, et al. (2003). Construction and characterization of a bacterial artificial chromosome library of banana (Musa acuminata Colla). Theor. Appl. Genet. 106: 1102-1106.

Wang JY, Chen YY, Liu WL and Wu YT (2008). Development and application of EST-derived SSR markers for bananas (Musa nana Lour.). Yi Chuan 30: 933-940.

Wang JY, Zheng LS, Huang BZ, Liu WL, et al. (2009). Development, characterization, and variability analysis of microsatellites from a commercial cultivar of Musa acuminata. Genet. Resour. Crop Evol. 57: 553-563. 